\title{
21st Century Learning Skills: A Challenge in Every Classroom
}

\author{
Joseline M. Santos ${ }^{1}$ \\ ${ }^{1}$ College of Education Bulacan State University, City of Malolos Bulacan, Philippines, Philippines, 3000
}

\begin{abstract}
Background/Objectives: The main objective of this study is to assess the 21st century learning skills of the students and the teaching practices in the 21st century classroom. Specifically, the study sought answers to the following questions: 1) How may the 21st century learning skills of the students be described in terms of eight (8) components of the 21st century learning skills? 2) How may the teaching practices be described in terms of 21 st century learning skills? 3) Is there a significant relationship between the perception of the students on their acquired 21st century learning skills and the teaching of 21st century learning skills in the classroom based on the perception of the teachers? 4) What is the implication of this study to the teachers, students and administrators of BulSU-CoEd? Methods/Statistical analysis: This study used a descriptive method of research. Data were gathered and analyzed. Student-t and Pearson $r$ product moment were used to test the hypothesis between the difference in the perceptions of the two groups of respondents and the relationship between them. Mean was also used to describe the summary of the questionnaire. Findings: The topmost skills of the students are; using technology as a tool for learning, self-direction skills, and collaboration. The topmost teaching practices are; local connections, creativity and innovation skills, and using technology as a tool for learning. The results indicated that the students' perception on the 21st Century skills that they acquired are not the same as what the teachers perceived to be what they transferred. Improvements/Applications: This research could serve as a basis for the seminars and workshops that may be provided to staff in-house or external.
\end{abstract}

\section{Index Terms}

$21^{\text {st }}$ century, Education, Technology, Teaching skills, Learning skills

\footnotetext{
Corresponding author : Joseline M. Santos

joseline.santos@bulsu.edu.ph

- Manuscript received July 15, 2017.

- Revised August 7, 2017; Accepted September 1, 2017.

- Date of publication September 30, 2017.

(c) The Academic Society of Convergence Science Inc.

2546-1583 $\odot 2017$ IJEMR. Personal use is permitted, but republication/redistribution requires IJEMR permission.
} 


\section{INTRODUCTION}

21 st century skills...are not new, just newly important [1]. Yes, 21st century learning skills are not new, educators are just realizing now that basic ideas and practices are the essentials. Nowadays, this term is the common topic for seminars and workshops and is frequently heard in different fora and discussions. Technically speaking, the twenty first century started on January 1, 2001 and will end on December 31, 2099, it is the current year of Anno Domini and known as the Common Era. But what is so different with this 21 st Century learning compared with that of the past that we need to spend time, money and effort to learn, explore and understand it to our advantage?

During the twentieth century, schools were described much different from today. Students' activities are mainly individual and very seldom for collaboration. Teachers assess learners based on summative with some formative elements which is best described by using percentage or numerical. Classroom was teacher-centric wherein the source of information was only the teacher. Learning was predominantly content with some few processes. The teaching approaches are only for students to learn and not to cater individual differences with low relevance to the learner, often low currency, and lack of context for the learner. Thinking skills was designed predominantly lower order and unstructured. This era also was learning about technology and with technology wherein students were given content and told processes. Students' self-management was based on rules with limited or no student input into framework. Academic promotion was with single level learning; gifted and talented students were focused on acceleration; learning styles were more predominantly read/write and auditory. And, feedback was very limited.

The Partnership for 21st Century Learning (P21) [2] has developed a unified, collective vision for learning known as the Framework for 21st Century Learning. This framework describes the skills, knowledge and expertise students must master to succeed in work and life; it is a blend of content knowledge, specific skills, expertise and literacies. Every 21 st century skills implementation requires the development of key academic subject knowledge and understanding among all students. Those who can think critically and communicate effectively must build on a base of key academic subject knowledge. Within the context of key knowledge instruction, students must also learn the essential skills for success in today's world, such as critical thinking, problem solving, communication and collaboration. [3]

21 st century learning is a collaboration of learners, educators and leaders. Students today are partly shaped by their environment, which is media rich, immediate, fast, engaging, dynamic and instantIt is electronic and digital, a communication medium implying instant gratification.[4]. Students today are given various labels - Digital Natives, Digital Children, Millennials, Neo-Millennials or 21st Century Learners. Through consistent exposure to a variety of digital media, they are engaged, motivated and learn by the use of digital technologies. They are adept in the use of digital media and are seemingly wired to use these tools. Students construct content and develop and evaluate processes. They also manage their learning based on moral and ethical approach; given opportunities to the broader use of multiple learning styles and application of multiple intelligences. And, feedback is coming from multiples sources such as self, peer and teacher.

The Philippines is now on its way addressing the lack of additional two years in the Basic Education. Different universities and colleges moved the opening of classes somewhere in August and September like UP, De La Salle and UST to agree with the practice of the other countries in the world. The new educational system of the Philippines which is known as $\mathrm{K}$ to 12 proposes holistic skills that will make graduates functional as one of the Business Agenda for Education of PBed stating, among other things, the continued enrichment of curriculum development in the context of the pillars of a new functional literacy.

The Philippines is just starting and there are lots of continuous designing, developing, utilizing and evaluating that need to be done. Philippine classroom must be redesigned to adhere to the demands and challenges of the 21 st century education. From the importance of education to the development of the country this 21 st century [5], similar to globalization, internationalization will ultimately lead to competition and improvement in the quality of education and an enhanced transfer of skills among nations (Behr, 2008), the ASEAN integration that will lead to shared jobs and prosperity [3] and the desire of the Philippines to cope up with the demands and changes in education lead the researcher to pursue this study of evaluating the readiness of administrators and teachers in planning the program, transferring the competencies, and evaluating the process, based on the P21 framework including the perception of the students, as Digital Natives, in the acquisition of knowledge and skills based on the demand of the 21 st century learning.

Bulacan State University (BulSU) being one of the leading provider of teachers in Bulacan, envisions to promote quality and relevant educational programs that meet international standards. BulSU since then, aims to be one of the best in producing graduates who are knowledgeable, skilled and competent. Through this research, students, teachers and 
administrators will be aware on how practices inside the classroom greatly influence the acquired learning skills of the students based on their perception. This research will also develop a program for the faculty to ensure more the attainment of empowered and competitive graduates through generation and transmission of knowledge in the discipline relevant and responsible to dynamically changing domestic and international environment. (BulSU-CoEd Goal, \#2).

\section{Helpful Hints}

This study sought answers to the following questions:

1. How may the 21 st century learning skills of the students be described in terms of:

1.1 critical thinking skills;

1.2 collaboration skills;

1.3 communication skills;

1.4 creativity and innovation skills;

1.5 self-direction skills;

1.6 global connections;

1.7 local connections; and

1.8 using technology as a tool for learning?

2. How may the teaching practices in the $21 \mathrm{st}$ century classroom be described in terms of:

2.1 critical thinking skills;

2.2 collaboration skills;

2.3 communication skills;

2.4 creativity and innovation skills;

2.5 self-direction skills;

2.6 global connections;

2.7 local connections; and

2.8 using technology as a tool for learning?

3. Is there a significant difference between the perception of the students and the perception of the teachers in terms of how the 21 st century learning skills are delivered and acquired in the classroom?

4. Is there a significant relationship between the acquired 21 st century learning skills of the students and the practices of the teachers in the delivery of 21 st century learning skills in the classroom based on their perception?

5. What is the implication of this study to the teachers, students and administrators of Bulacan State University, College of Education?

\section{A. Methods}

This study used a descriptive method of research. An adapted questionnaire formulated by Hixson, Ravitz \& Whisman (2012) of West Virginia was utilized. The instrument consists of a framework that measures $21 \mathrm{st}$ century teaching and learning. The questionnaire was originally made for the teachers; the researcher modified the content to make it suitable for the level of the students. Data were gathered and analyze with the use of IBM-SPSS ver. 17 Statistical Software. A t-test for paired samples was used to test the hypothesis that there is no significant difference between the perception of the students and teachers. Pearson $r$ was also applied to test whether significant relationship exists between the two variables. Mean also was used to identify the level of 21 st century teaching-learning skills among students and teachers.

The fourth year BulSU-CoEd students consist of two hundred twelve (212) Bachelor in Elementary Education (BEEd); five hundred fifty six (556) Bachelor in Secondary Education (BSEd); forty one (41) Bachelor in Technical Teacher Education (BTTE) and 35 teachers who have handled the said students are the subjects of the study. Among the given number of students only one hundred sixty three (163) BEEd, three hundred twenty eight (328) BSEd, thirty five (35) BTTE and twenty six (26) teachers were able to answer the questionnaire. The students and teachers were asked to answer a survey for measuring 21 st century for teaching and learning by Hixson, Ravitz \& Whisman (2012).

\section{RESEARCH RESULTS}

After the data were tabulated, computed and analyzed, the following are the results:

\begin{tabular}{lcl}
\multicolumn{2}{l}{ Table 1. STUDENTS' 21ST CENTURY LEARNING SKILLS } \\
\hline 21st Century Learning Skills & Mean & $\begin{array}{l}\text { Verbal } \\
\text { Interpretation }\end{array}$ \\
\hline \hline $\begin{array}{l}\text { Using Technology as a Tool } \\
\text { for Learning }\end{array}$ & 3.89 & $1-3$ times per week \\
$\begin{array}{l}\text { Self-Direction Skills } \\
\text { Collaboration Skills }\end{array}$ & 3.59 & $1-3$ times per week \\
Creativity And Innovation & 3.51 & $1-3$ times per week \\
Skills & 3.51 & $1-3$ times per week \\
Communication Skills & 3.44 & $1-3$ times per month \\
Critical Thinking Skills & 3.39 & $1-3$ times per month \\
Local Connections & 3.37 & $1-3$ times per month \\
Global Connections & 3.33 & $1-3$ times per month \\
\hline
\end{tabular}

Table 1 presents the eight 21 st century learning skills based on the students' perception. It clearly shows the use of technology as a tool for learning (3.89) is a very evident skill for the students as they practice it 1-3 times a week. These are the students of 'Net Generation' as what Topscott (2001) defined the generation of technologically advanced students. Next in line is self-direction skills (3.59) which they also practice 1-3 times per week. This has proven that students in this generation, though disturbed with media, still know that they need to actively participate in classes, network with other students, talk to their professors, have good time management, set personal goals, and actually go to class in order to succeed (Douglas and Morris, 2014). Next are collaboration skills and creativity and innovation 
skills (3.51) that is also practice for 1-3 times per week. Wismath (2015) found out in her study that optimal "co-learning" on problem solving is highly contextual. It depends on the person and his/her preference, on the problem, the purpose or goal being worked towards, and the cycles of the problem-solving process. Student's personality is one of the factors that makes collaborative learning a success. Students nowadays are very creative; most of them give their best to produce quality output. When students feel truly passionate about their education, the experience of learning becomes uniquely their own (Serdar, 2015). Other skills followed which they practice 1-3 times a month; communication skills (3.44), critical thinking skills (3.39), local connection (3.37) and global connections (3.33). Table 2: Teaching Practices that Developed the 21st Century Skills of the Students

Table 2. Teaching Practices That Developed the 21St CENTURY SKILls OF THE STUDENTS

\begin{tabular}{lll}
\hline $\begin{array}{l}\text { 21st Century Learning } \\
\text { Skills }\end{array}$ & Mean & $\begin{array}{l}\text { Verbal } \\
\text { Interpretation }\end{array}$ \\
\hline \hline $\begin{array}{l}\text { Local Connections } \\
\begin{array}{l}\text { Creativity And Innovation } \\
\text { Skills }\end{array}\end{array}$ & 3.91 & $1-3$ times a week \\
$\begin{array}{l}\text { Using Technology As A Tool } \\
\text { For Learning }\end{array}$ & 3.89 & $1-3$ times a week \\
Critical Thinking Skills & 3.81 & $1-3$ times a week \\
Communication Skills & 3.80 & $1-3$ times a week \\
Self-Direction Skills & 3.72 & $1-3$ times a week \\
Collaboration Skills & 3.62 & $1-3$ times a week \\
Global Connections & 3.40 & $1-3$ times a month \\
\hline
\end{tabular}

From the results presented in Table 2, local connections (3.91) which they practice 1-3 times a week is rated highest by the teachers. Local connections refer to students being able to apply what they have learned to local contexts and community issues. It is very clear how the teachers transfer learning to the future teachers of the country by applying the localization and contextualization thrusts of the Enhanced Basic Education Curriculum which direct all schools and learning programs to relate curriculum content and competencies to the social and educational context of communities being served (DepEd Order No. 51, s. 2014). Next is creativity and innovation skills that is being practices 1-3 times a week (3.90) which refers to students being able to generate and refine solutions to complex problems or tasks based on synthesis, analysis and then combining or presenting what they have learned in new and original ways. This is the same idea of Outcome Based Education (OBE). Spady and Marshall advocate transformational OBE, in which outcomes are derived from careful analysis of what students must be able to do to succeed in the future. These transformational outcomes are be demonstrations of life "performance roles" such as problem solver and teacher (Spady 1994). Third in rank is the use of technology as a tool for learning (3.89) being practiced 1-3 times a week. It refers to students being able to manage their learning and produce products using appropriate information and communication technologies. Effective use of technology in educational environments and its successful integration increases the productivity of instructional processes. Constant and good-quality support supposed to be provided for teachers is quite important for technology use in educational environments (Eristi, et al, 2012). Next in rank which are being practiced 1-3 times a week are critical thinking skills (3.81); communications skills (3.80); self-direction skills (3.72); collaboration skills (3.62); and global connections that is being practice for 1-3 times a month (3.40).

\begin{tabular}{|c|c|c|c|c|c|}
\hline . & & & $\mathrm{N}$ & Correlation & Sig. \\
\hline Pair 1 & $\begin{array}{l}\text { STUDENTS } \\
\text { TEACHERS }\end{array}$ & \& & 48 & .442 & .002 \\
\hline
\end{tabular}

Paired Samples Correlations is presented in Table 3. It shows the response of the students and teachers in the forty-eight (48) specific practices of the eight frameworks set by the West Virginia Department of Education (2012). Having 0.442 value of correlation, it means there is a positive, moderate relationship existing between the variables. Since it is positive, therefore we can say that the perception of the students is directly correlated with the perception of the teachers in terms of the 21 st century learning skills. This is further supported by the computed probability of 0.002 . Since the probability is less than 0.05 alpha, it means Ho is rejected and that we have enough reasons to believe that there is a significant relationship existing between the two variables. As what Allan Odden and Marc Wallace (2003) observe that "improved classroom instruction is the prime factor to improve student achievement gains" (Focus, 2011, p.51). Teacher plays a big role in the learning of the students. They are very influential to the young minds of the learner.

Table 4. PAIRED SAMPLES T-TEST

\begin{tabular}{|c|c|c|c|c|c|c|c|c|c|}
\hline & & & Paire & $\overline{D i f f e r e n c}$ & & & & & \\
\hline & & Mean & $\begin{array}{c}\text { Std. } \\
\text { Deviation }\end{array}$ & $\begin{array}{c}\text { Std. } \\
\text { Error }\end{array}$ & $\begin{array}{r}95 \% \mathrm{Cc} \\
\text { Interv } \\
\text { Diff }\end{array}$ & $\begin{array}{l}\text { fidence } \\
\text { lof the } \\
\text { rence }\end{array}$ & t & $\mathrm{df}$ & $\begin{array}{l}\text { Sig. } \\
\text { (2- } \\
\text { tailed) }\end{array}$ \\
\hline & & & & & Lower & Upper & & & \\
\hline Pair 1 & $\begin{array}{l}\text { STUDE } \\
\text { NTS - } \\
\text { TEACH } \\
\text { ERS }\end{array}$ & -.22458 & . 24673. & . 03561 & - -29623 & -.15294 & -6.306 & 47 & . 000 \\
\hline
\end{tabular}

To determine whether significant difference exists between the two variables, the researcher submitted the data into a paired samples t-test which is shown in Table 4 . The probability value of 0.000 indicates that the difference in the mean scores of the two variables are proven to be significant. 
Despite the moderate correlation which existed between the perceptions of the students and the teachers, the difference in their mean is deemed to be significant. This led the researcher to conclude that the perception of the students does not conform to the perception of the teachers. The means tell that the teachers' perception is significantly higher than the students perception. The rankings are varied (see Table 1 and 2), among the eight areas it is only the use of technology as a tool for learning gets in the top 3 for both; it is the highest in rank for the students and the third in rank for the teachers.

\section{Conclusion}

The results of the survey indicate that the students' perception on their acquired 21 st century skills are not the same as what the teachers expect since that teachers rated themselves higher on the teaching practices they are doing inside the classroom anchored on the skills of 21 st century learning. Teachers, based on the result of the survey deliver their lesson containing the practices on how to support students' learning, but so much of the teachers' desire to develop students holistically, students do not acquire everything. There are so many things to consider in this issue. Since teachers already have mastery of the lesson and they are teaching the subjects for number of years it is possible that they are used to it and thinking that the subject is easy without considering that students are encountering the subject only for the first time. Teachers tend to forget the key points in their subject; these are the parts of the lesson that are challenges for many of the students. Students at young age are pre-occupied with so many things, family, school, peers, social media and others. Sometimes, the eagerness of the teacher to hone the potential of the students fails because of the students' unwillingness to learn. "The teacher opens the door and you enter by yourself" a Chinese proverb that explains the desire of the teacher to impart learning but if students don't accept it nothing will happen.

The result of this study will serve as an eye opener to the student, teachers and administrators. Students are recommended to focus on the other skills that they fail to realize. It is good to strengthen their potentials but there are still other areas in their personality that they have to develop. For the teachers, delivery of the lesson should be clearly done; consider the differences among learners, their level of performance, motivation and experiences. This research is for the administrators; to be a basis for the seminars to be to be conducted in-house or to be attended outside. Consider the 21 st century learning skills to help teachers improve their classroom practices in the delivery of the lesson. Teaching as a profession is known to be noble; extend a hand, walk an extra mile to prepare the students in the challenges of the 21 st century.

\section{REFERENCES}

[1] Schmoker, M. 2011. FOCUS: Elevating the Essentials to Radically Improve Student Learning. Alexandria, Virginia, USA. ASCD.

[2] P21 Framework Definitions (2015). P21 Partnership for 21st Century Learning. Retrieved from http://www.p21.org/ storage/documents/docs/P21_Framework_Definitions_New_ Logo 2015.pdf

[3] Asian Development Bank(2016). ASEAN Community 2015: Managing Integration for Better Jobs and Shared Prosperity. Retrieved from https://www.adb.org

[4] Nakrani, Alpeshkumar. 2013. 21st Century Teachers and Learners: A Perspective. Retrieved from http://carnegieendowment.org/1999/09/14/education-globalization-anddemands-of-21 st-century-pub-44

[5] Birdsall, Nancy (1999). Education, Globalization and Demands of the 21st Century. Carnegie Endowment for International Peace. Retrieved from http://carnegieendowment

[6] Eason, G., Noble, B., \& Sneddon, I. N. (1955). On certain iTechakanont, K. (2014). Managing Integration for Better Jobs and Shared Prosperity in the ASEAN Economic Community: The Case of Thailand's Automotive Sector. ILO. 